\title{
Alteraciones anatómicas de la vía biliar principal de etiología mecánica como hallazgos durante colangiografías intraoperatorias.
}

\begin{abstract}
Anatomical alterations of the main bile duct of mechanical etiology as findings during intraoperative cholangiography.
\end{abstract}

Mauro Andrés Perdomo ${ }^{1}$

ORCID https://orcid.org/0000-0001-6470-6107

DOI 10.31837/cir.urug/5.2.10

Martín Bentancur ${ }^{2}$

ORCID https://orcid.org/0000-0003-4816-2095

Pablo Valsangiácomo ${ }^{3}$

ORCID https://orcid.org/0000-0003-2028-5552

Daniel González ${ }^{4}$

ORCID https://orcid.org/0000-0003-3916-9201

Recibido: 26 de marzo 2020

Aceptado: 20 de junio 2021

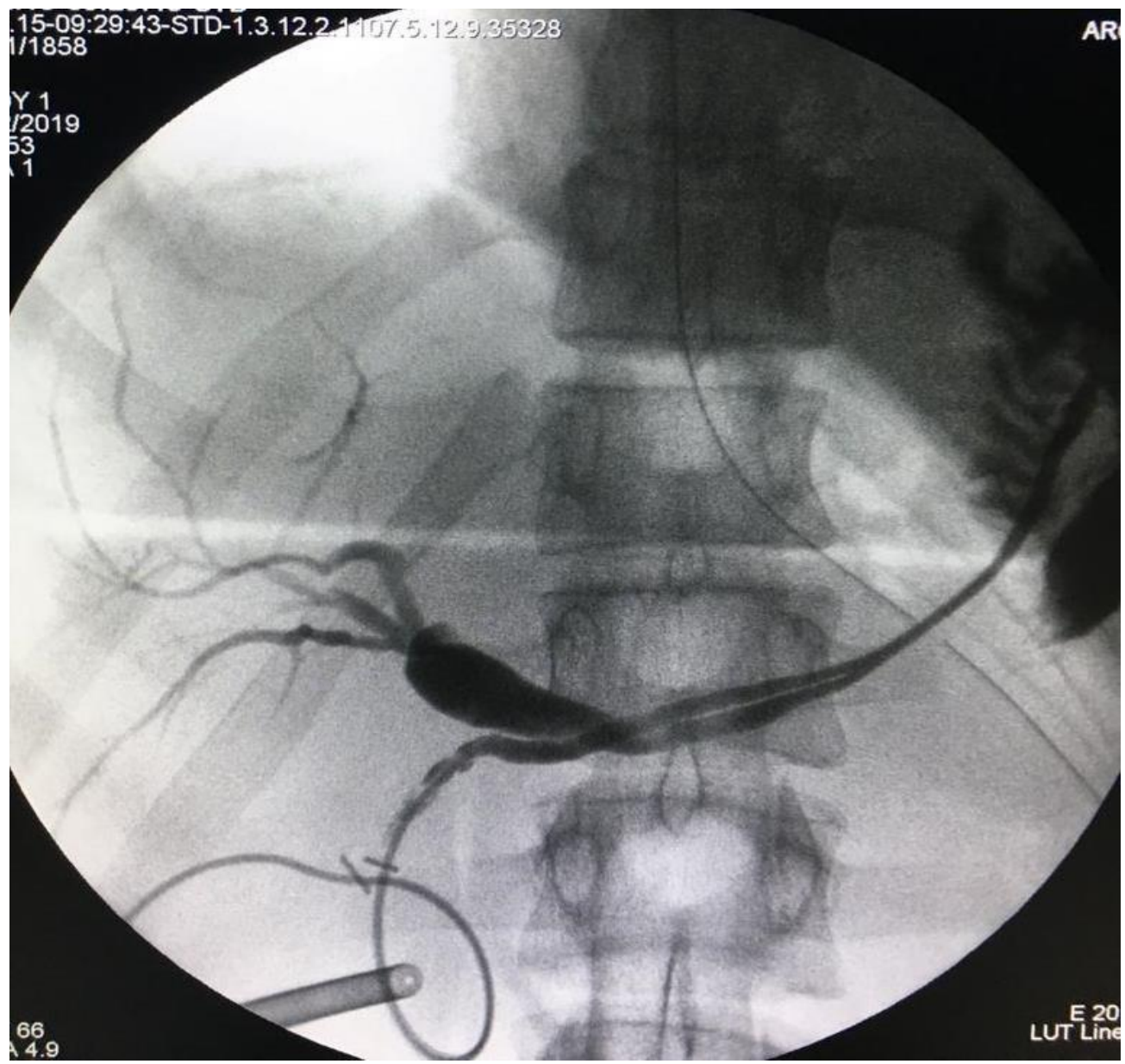

1,2,3,4, Universidad de la República. Facultad de Medicina. Hospital Maciel. Clínica Quirúrgica 3. Montevideo, Uruguay.

mauroandresperdomo@gmail.com 
Se presentan dos colangiografías intraoperatorias realizadas en el contexto de colecistectomías laparoscópicas coordinadas.

\section{Imagen A}

Paciente de sexo masculino, 18 años. Luchador de kick-boxing. Ingresa con cuadro compatible con pancreatitis aguda litiásica.

Ecografía abdominal luego de remisión: páncreas de aspecto habitual, vía biliar principal sin alteraciones. Vesícula con escaso barro biliar.

\section{Descripción}

Se evidencia una franca horizontalización de la vía biliar principal, acompañada por un conducto cístico largo que transcurre en paralelo y que impresiona pasar por delante de la misma. Esta relación determina una compresión con dilatación proximal del hepático común.

La convergencia biliar superior no es modal, apreciándose tres conductos, pero sin lograr identificar el árbol biliar izquierdo en esta imagen.

El duodeno se contrasta topografiado en el hipocondrio izquierdo, lo que nos permite sospechar una falta de acolamiento del duodeno-páncreas, hecho que podría explicar su ubicación.

\section{Respuesta}

En este caso, la imagen responde al desplazamiento de contenido abdominal al hemitórax izquierdo como consecuencia de una gran hernia diafragmática como se puede ver en las siguientes imágenes tomográficas. 


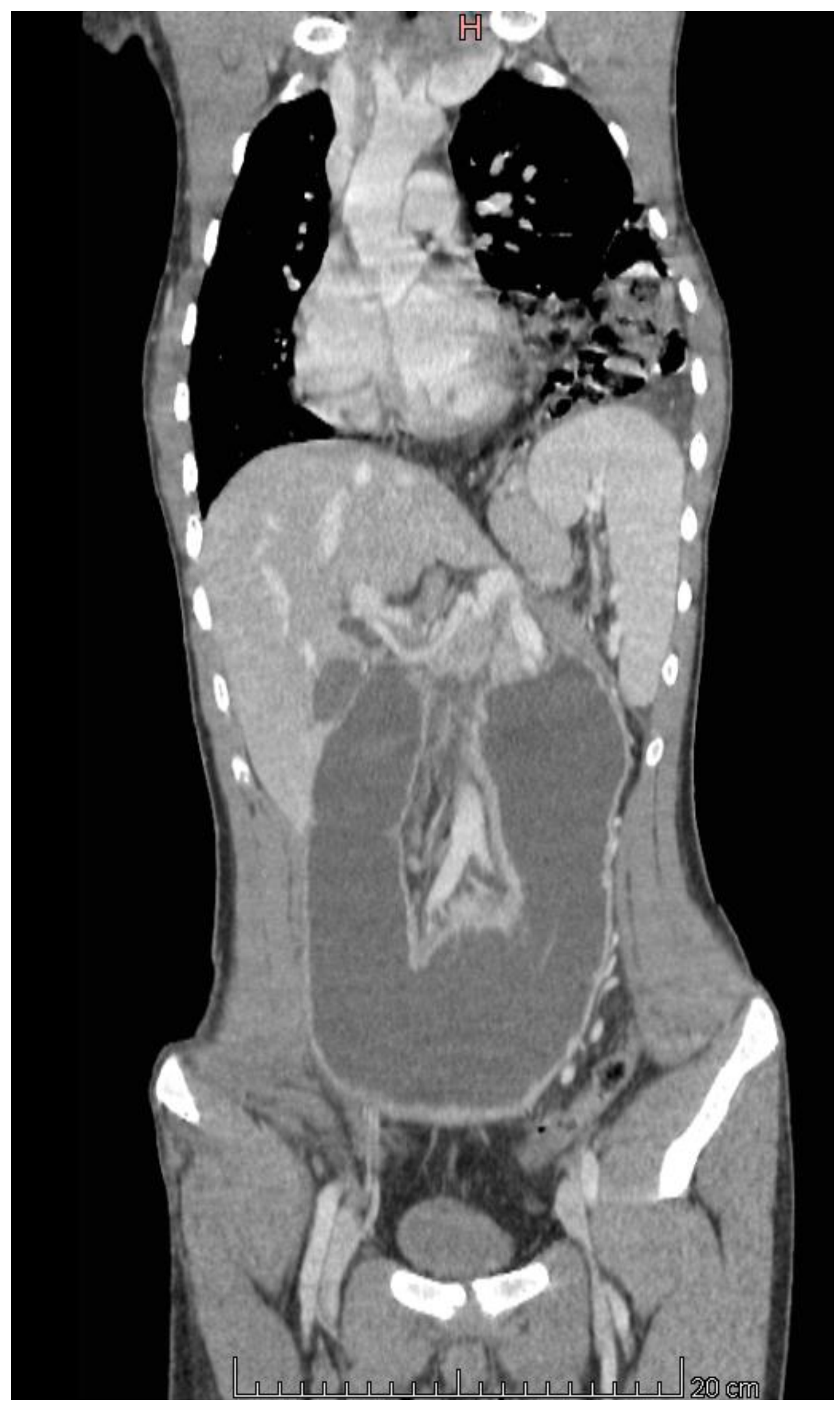




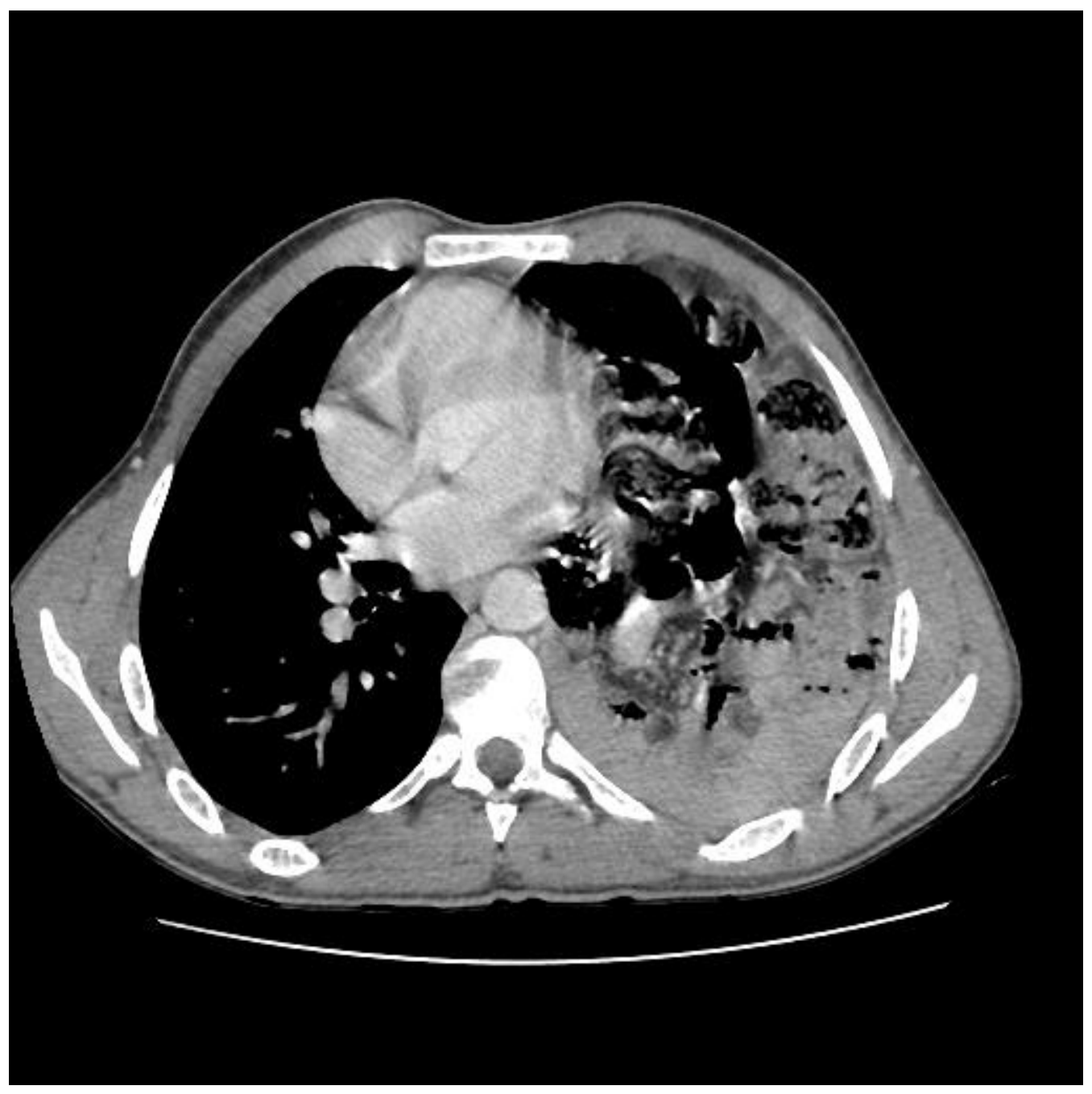

En el corte coronal se puede apreciar una cámara gástrica distendida que alcanza la pelvis como consecuencia de la estenosis distal causada por la hernia diafragmática. A su vez se observa el pedículo hepático horizontalizado, así como también las asas delgadas ocupando el hemitórax izquierdo del paciente. 


\section{Imagen B}

Paciente de sexo masculino, 61 años. Esofagectomía total video-asistida por carcinoma epidermoide de 1/3 medio de esófago torácico. En el postoperatorio cursa colangitis aguda litiásica, que requiere ERCP con papilotomía y extracción de litos.

Se realiza colecistectomía laparoscópica de coordinación a las 48 horas.

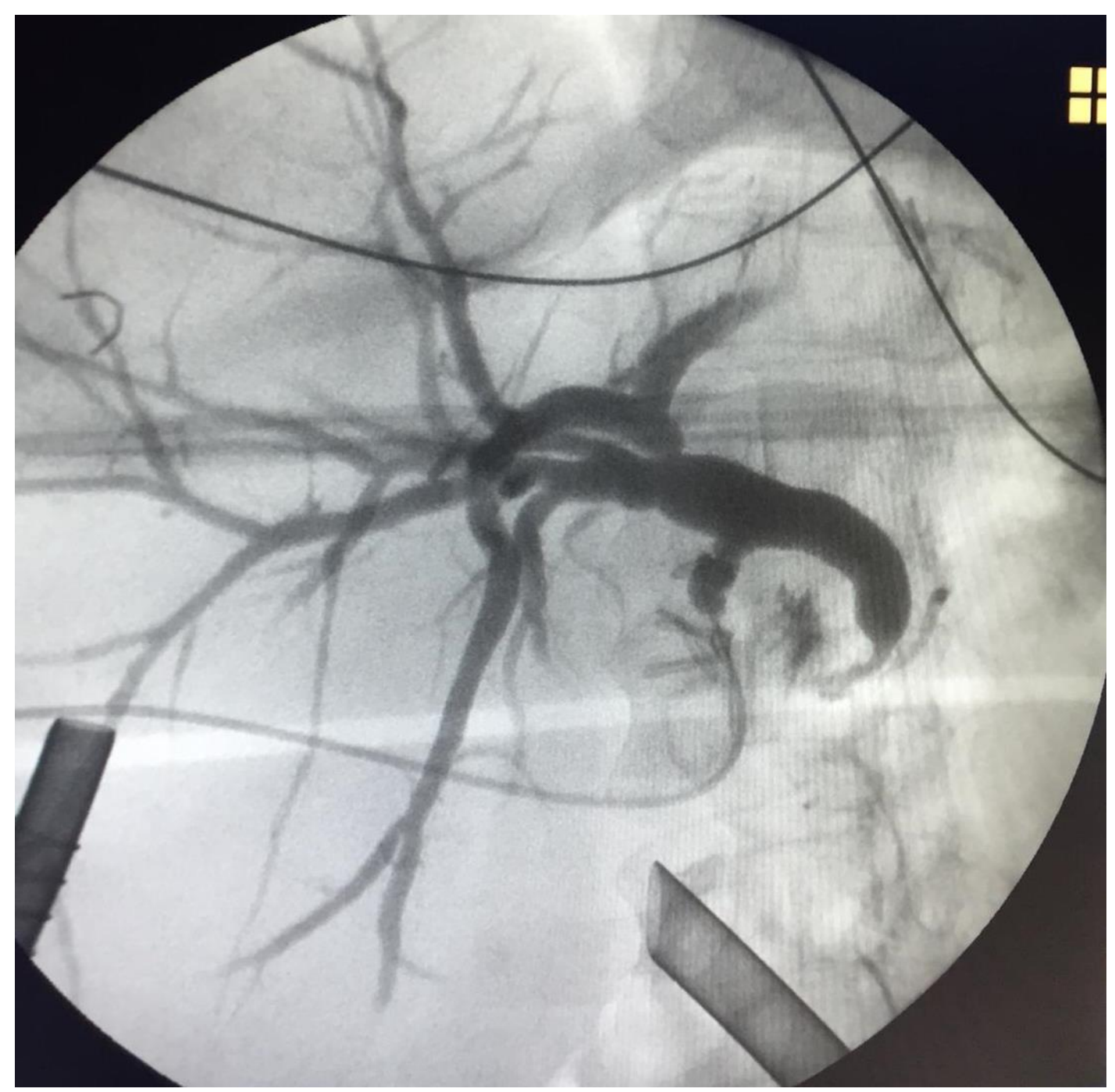

\section{Descripción}

En esta imagen se logra contrastar completamente el árbol biliar levemente dilatado, evidenciando un trayecto horizontal del hepático común y colédoco proximal, sin defectos de relleno. 


\section{Respuesta}

La horizontalización de la vía biliar principal de este caso es secundaria a la alteración anatómica por la maniobra de Kocher-Vautrim durante el tiempo abdominal de la cirugía previa. 